\title{
DOE|ER/60376-T4
}

\section{FINAL REPORT}

\section{TITLE: Shelf Export of Particulates/Transport in Continental Margin Waters}

DE-FG09-85ER60376

\section{Department of Marine, Earth and Atmospheric Sciences North Carolina State University Raleigh, NC 27695 DISCLAIMER}

This report was prepared as an account of work sponsored by an agency of the United States Government. Neither the United States Government nor any agency thereof, nor any of their employees, makes any warranty, express or implied, or assumes any legal liability or responsibility for the accuracy, completeness, or usefulness of any information, apparatus, product, or process disclosed, or represents that its use would not infringe privately owned rights. Reference herein to any specific commercial product, process, or service by trade name, trademark, manufacturer, or otherwise does not necessarily constitute or imply its endorsement, recommendation, or favoring by the United States Government or any agency thereof. The views and opinions of authors expressed herein do not necessarily state or reflect those of the United States Government or any agency thereof.

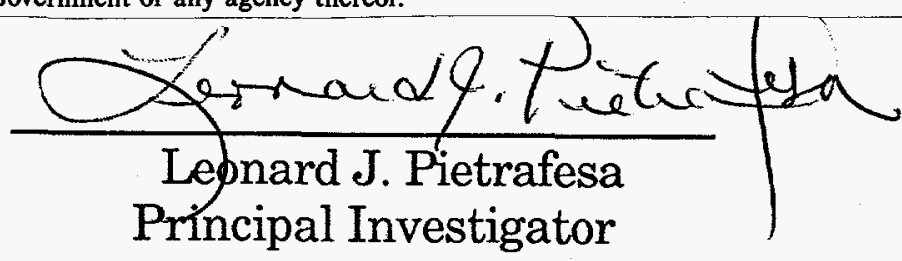




\section{DISCLAIMER}

Portions of this document may be illegible in electronic image products. Images are produced from the best available original document. 
Summary of Accomplishments During Present Funding Period: 15 September, 1987 - 14 September, 1988

A. Overview:

During the present funding period, research activities at NCSU have been directed towards: publishing the results of SEEP-I; publishing further results from NCSU's South Atlantic Bight studies; designing and constructing four cages which house the 3 NCSU and 1 BNL RDAcoustic Doppler Current Profilers used successfully in SEEP-II, calibrating all current meters, transmissometers, thermister chains and conductivity pressure and temperature sensors for SEEP-II phases 2 and 3; determining the temporal and spatial scales of physical processes observed during phase 1 of SEEP-II in preparation for finalizing the mooring positions and sampling intervals for SEEP. II; shipping all NCSU gear to the URI and ODU; and successful deployment of NCSU SEEP-II, phases 1 and 2 moorings.

B. Major Accomplishments:

(a) Have created a mathematical mode of the evolution, persistence and breakdown of the MAB Shelf/Slope Front (paper in prep).

(b) Have created a conceptual model of the transport mechanisms and transport pathways of particles during SEEP-I's Spring, 84 experiment from the 80 to $120 \mathrm{~m}$ isobaths. The bottom boundary layer is the evacuation route at $1 \mathrm{~cm} / \mathrm{sec}$ at the $80 \mathrm{~m}$ and $2 \mathrm{~cm} / \mathrm{sec}$ at the $120 \mathrm{~m}$ isobaths (J.C. Lee dissertation), as shown in Figures 1 and 7.

(c) Have created a mathematical model of coastal sealevel which 

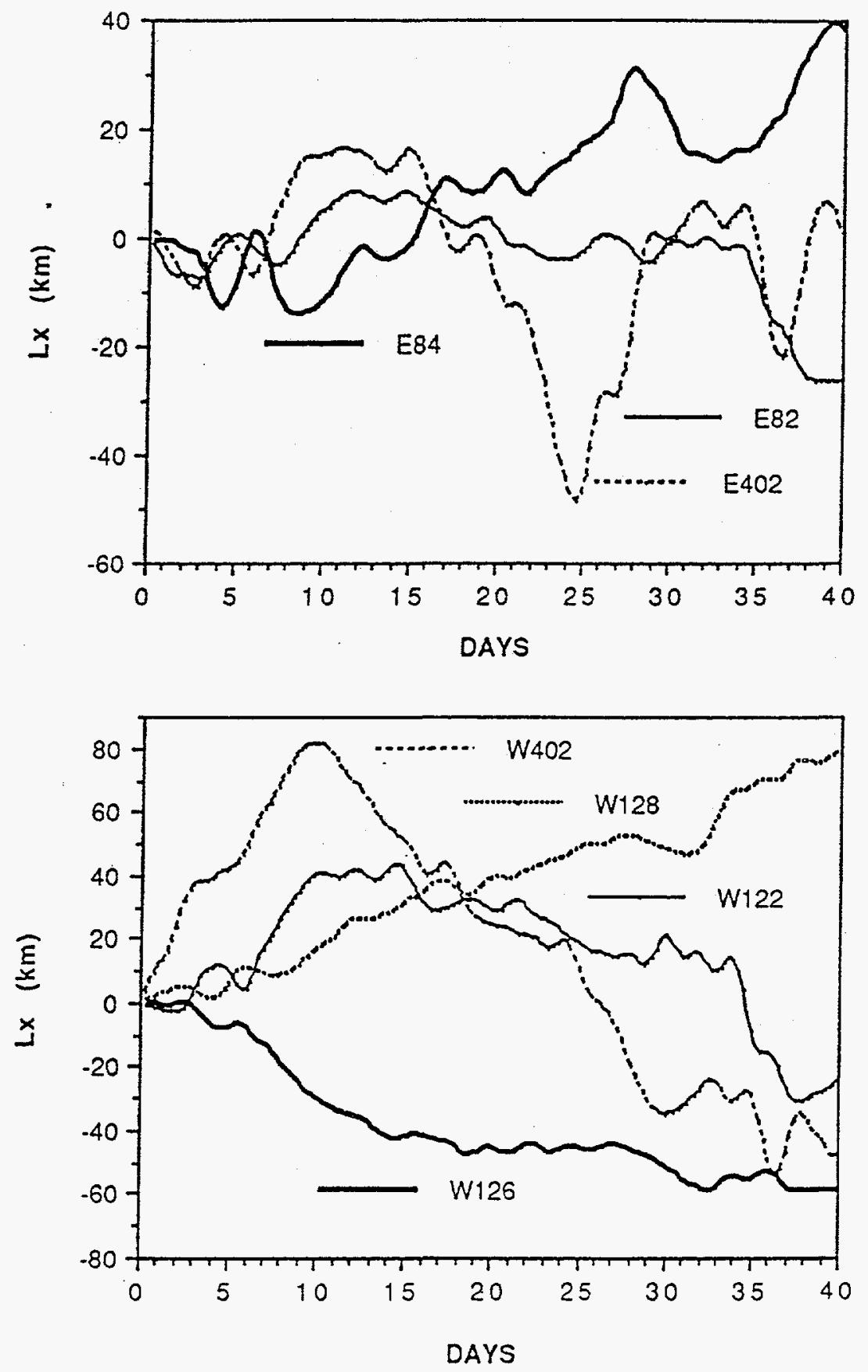

Figure 1. Onshore (negative) ail offshore (positive) particle pathlengths (in kilometers) over the SEEP-I Spring Bloom 40 day experiment. Note that offshore particle excursions occur only in the near bottom layers at all sites, including E8-4, W12-8 and W8-4 (cf. Figure 19). 
can predict subinertial frequency fluctuations virtually identically from Woods Hole to Sandy Hook and Beaufort to Savannah using observed coastal winds as input (paper in prep) as shown in Figure 2.

(d) Have proven that the invasion of the red tide dinoflagelates to

- Onslow Bay, North Carolina from Naples, Florida occurred via Gulf Stream frontal filament and wind driven currents during October, 1987 (paper submitted) as shown in Figure 3.

(e) Have created a complete transportation route scenario for the passive recruitment of larvae and juvenile finfish across the continental margin of the north SAB and south MAB (1 paper published, 2 papers in prep).

(f) Have described the exchange of water masses between the $\mathrm{SAB}$ and $\mathrm{MAB}$ around Cape Hatteras using historical data (paper in review).

(g) During the spring mean parabathic flows are to the west and southwest and are linked to a diabathic pressure gradient related to a bowl shaped sea surface depression located between the Gulf Stream and the outer shelf throughout the MAB region as shown in Figure 4a,b. Synoptic scale fluctuations were caused locally by the wind and non-locally by the remote forcing of Gulf Stream frontal meanders (paper in prep).

(h) Transmissometer absorption and fluctuations in light attenuation are highest in the bottom boundary layer (J.C. Lee dissertation) as shown in Figure 5.

(i) The cross-shelf wind component accumulates towards the south while the alongshelf wind stabilizes towards the east after about 

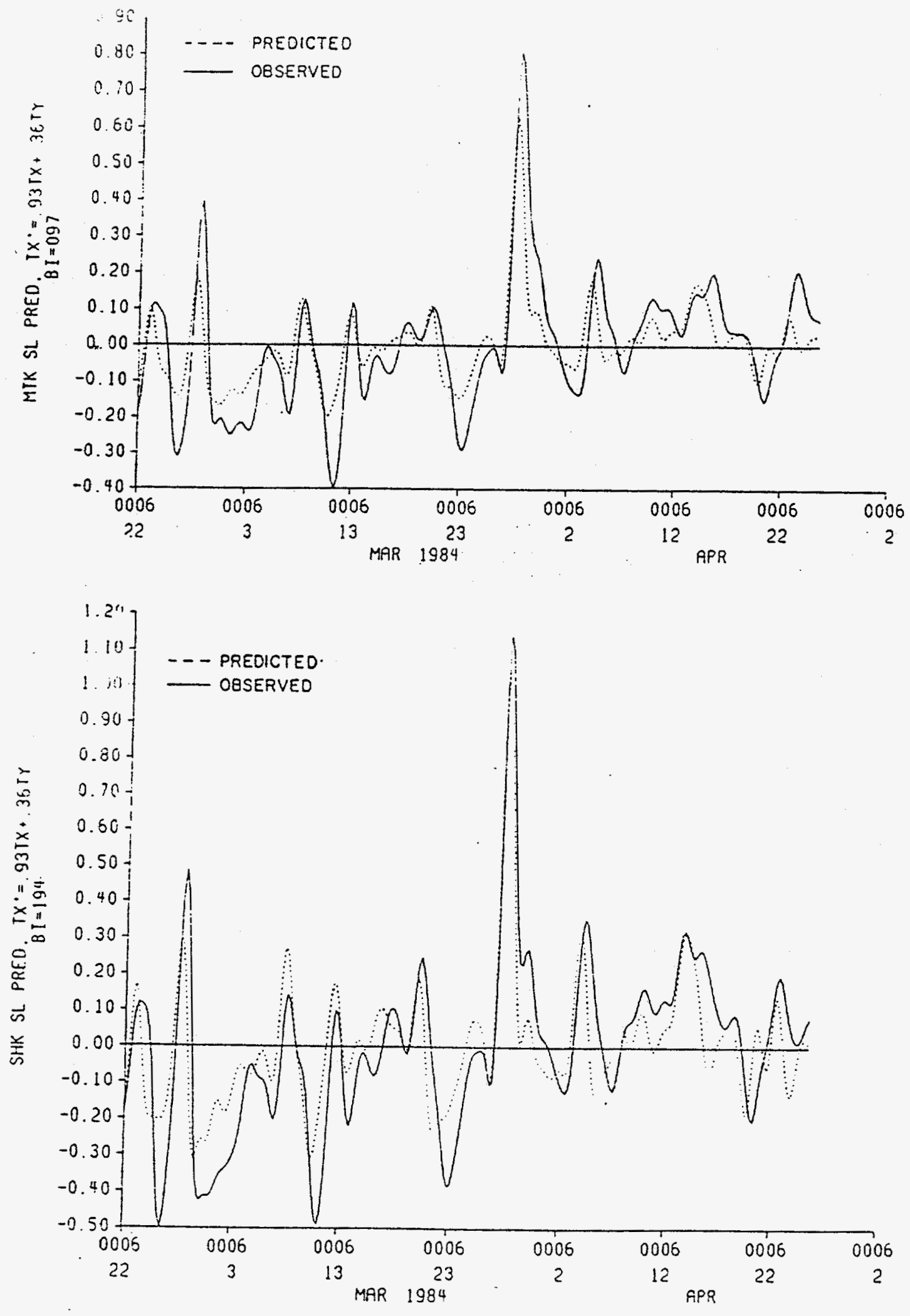

Figure 2. Observed sealevel vs. model predicted sealevel at Montauk (L.I.) and Sandy Hook (N.J.) using coastal winds at the BNL as input. 


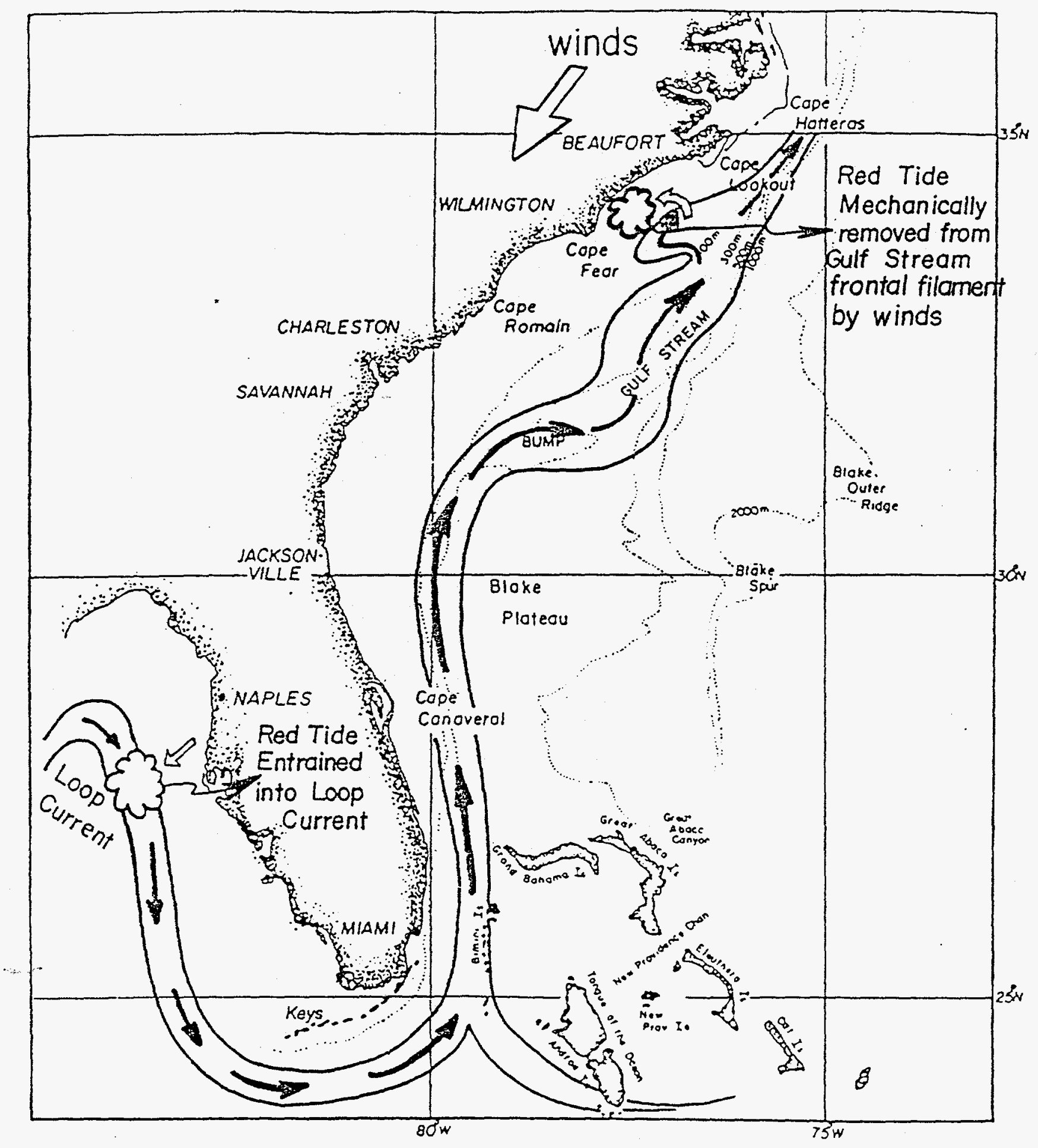

Figure 3. Transport pathway of the redtide dinoflagelate as it was transported by the Gulf Stream and frontal filaments to the North Carolina shelf where it was subsequently driven by wind towards the coast in October 1987. This was the first recorded infestation of North Carolina coastal waters by the Red Tide. 
(a)

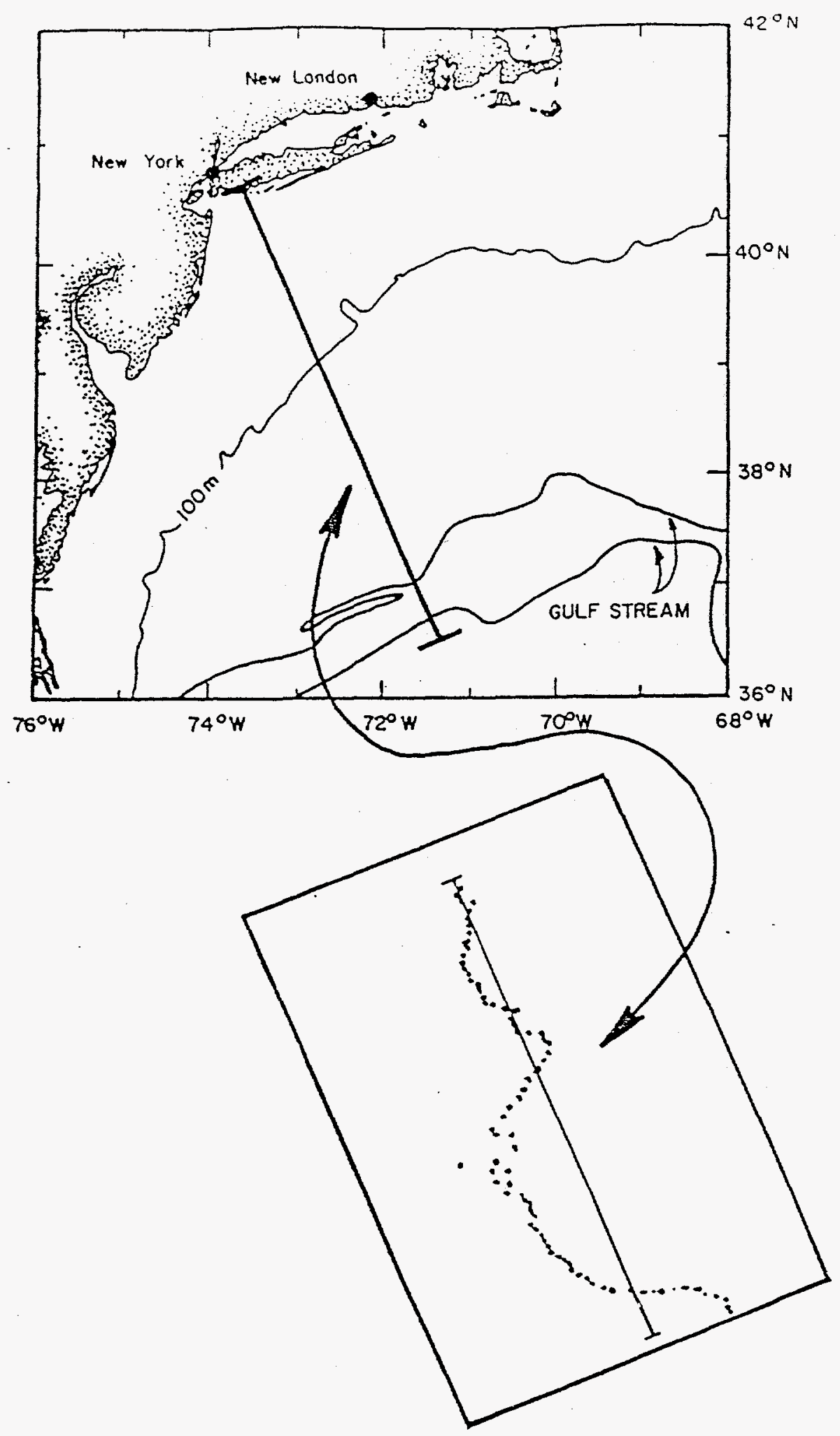

Figure 4 (a). Seasurface temperature map, i.e. VHRR imagery of oceanic features detected during passage 1148 (along the line indicated) of the Seasat satellite.

(b) Seasurface topography map along the bracketed line (pass \#148) detected by the Seasat altimeter. There is a drop in sealevel from the Gulf Stream to the middle of the North Atlantic and a subsequent rise of sealevel up the slope and shelfbreak of the Mid Atlantic Bight. 


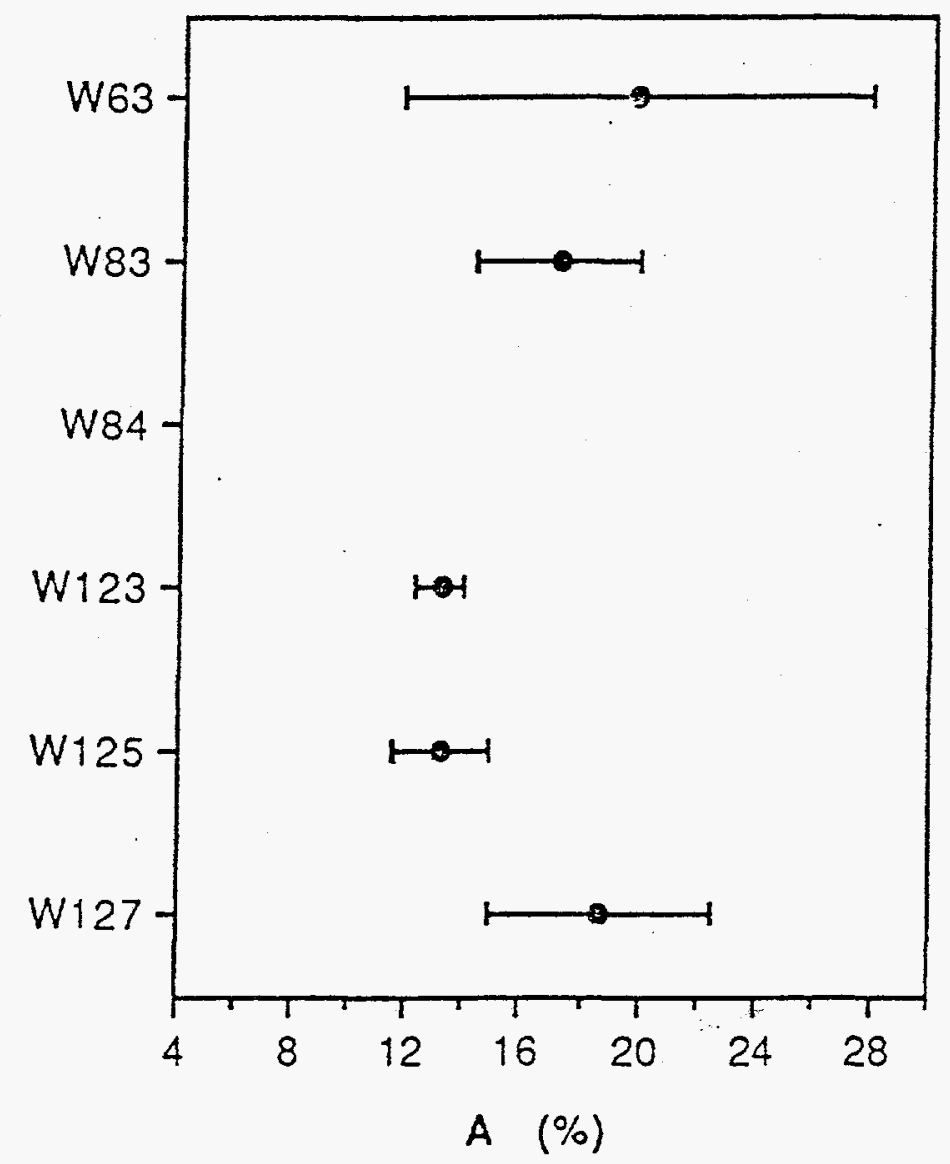

Figure 5. Means and fluctuations in transmissometer absorption as a function of location on the west line of SEEP-I. Highest values of both means and fluctuations are at the near bottom sites on the 60,80 and $120 \mathrm{~m}$ isobaths. 

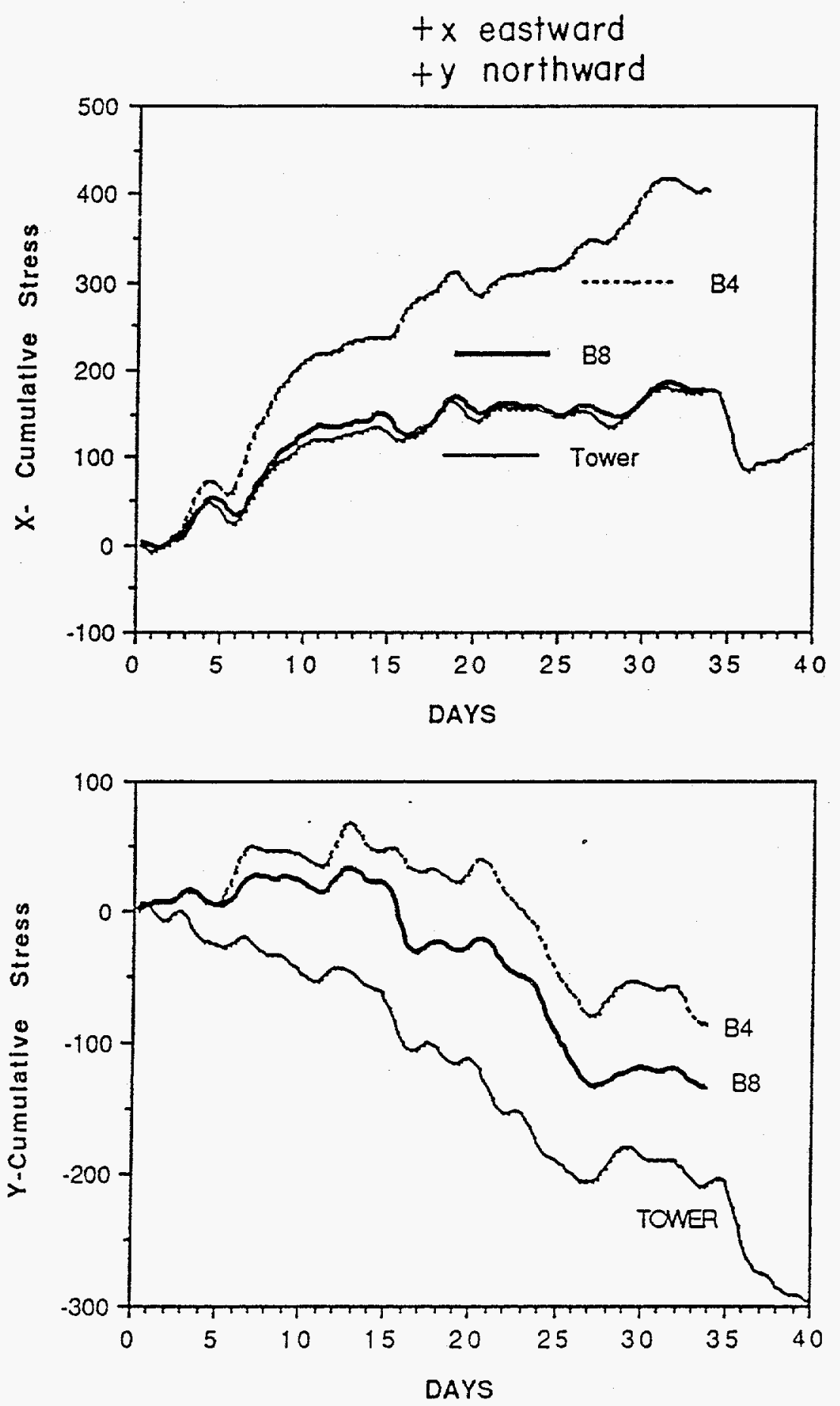

Figure 6. Cumulative windstress components (in an E-W/N-S coordinate system) from Buoys 4 and 8 and the BNL tower during SEEP-I. 
1.5 weeks during the spring (J.C. Lee dissertation) as shown in Figure 6.

(j) Offshore/onshore particle excursions are inversely related to temperature in the BBC as shown in Figures 1a,b, and directly related to temperature in the water column interior, Figure 7c.

- These relationships are coupled to disabathic movements of the SSF during the Spring Bloom (J.C. Lee dissertation).

(k) Seasat altimeter data define sea surface troughs or bowlshaped depressions in both the MAB and $\mathrm{SAB}$ (as shown in Figure 8) between the Gulf Stream front and the outer shelf. These depressions suggest counter-clockwise gyres in both the MAB and $\mathrm{SAB}$ with southward slope currents present to balance the seaward drop of sealevel. Near bottom flows associated with these longshore jets are directed offshore. The cross-shelf sea surface slopes are of order $10^{-6}$ to $10^{-5}$ sufficient to drive 10 to $100 \mathrm{~cm} / \mathrm{sec}$ longshore flows (paper in prep).

(1) Coastal plain estuary plumes can turn right, left or spray outward as they outwell onto the MAB and SAB shelves. Plume fronts may or not exist. The important parameters are vertical stratification, topography, the strength and direction of the upper and lower layer flows at the mouth and the strength and direction of ambient inner shelf currents. The plume dynamics were mathematically modeled and applied to the Savannah and Cape Fear Rivers and Chesapeake and Delaware Bays (2 papers published).

(m) Described summer momentum fluxes in the South Atlantic 

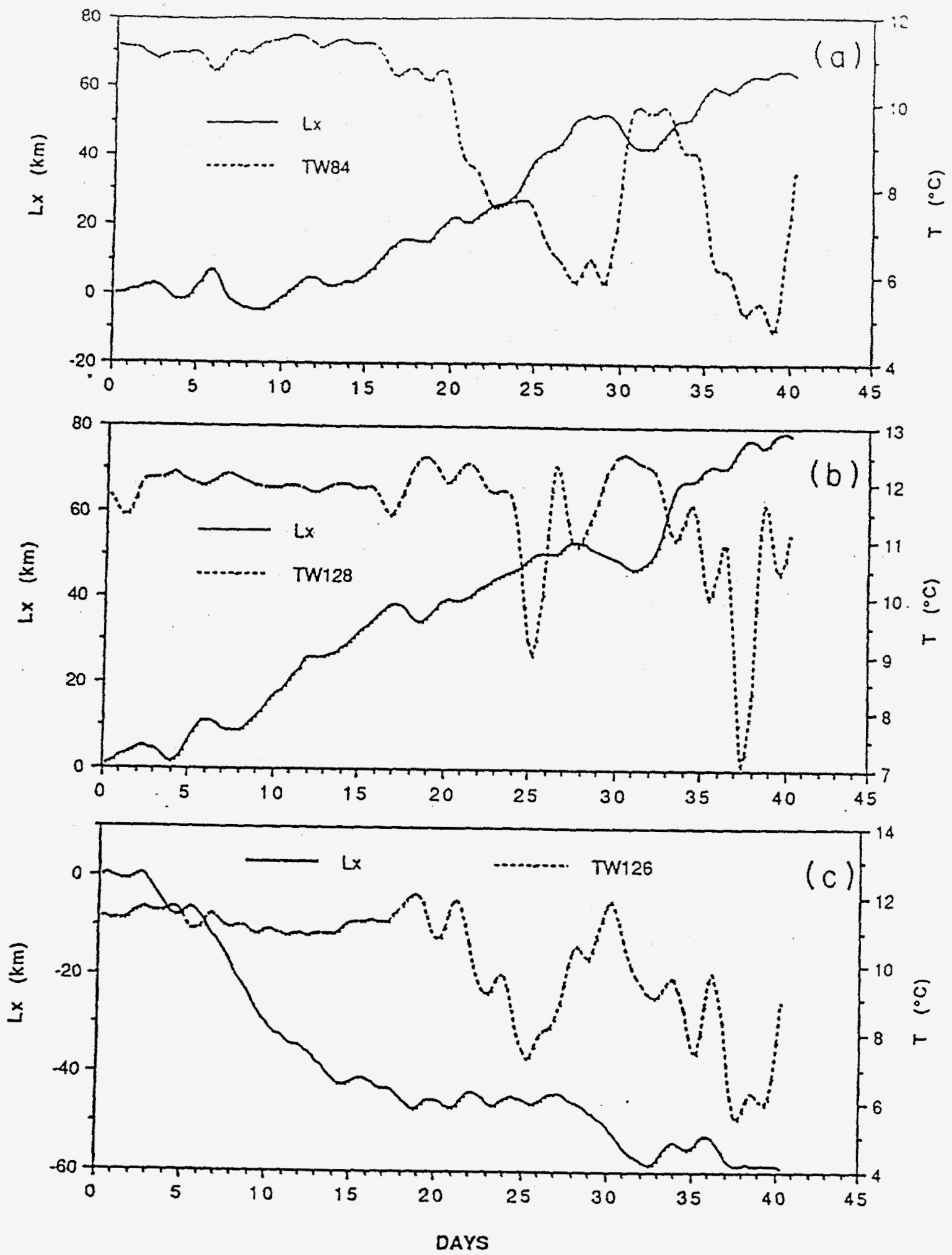

Figure 7. Onshore (negative) and offshore particle transport pathlengtho and water temperatures at near bottom sites (a) W8-4 and (b) W12-8 and interior site (c) W12-6 during SEEP-I. Note, net particle pathways are offshore at an average speed of $1.5 \mathrm{~km} /$ day at site $W 8-4$, and $2 \mathrm{~km} /$ day at site $W 12-8$, but onshore at site W12-6. Also note that as Temperature and pathlength (positive offshore) are inversely correlated. 

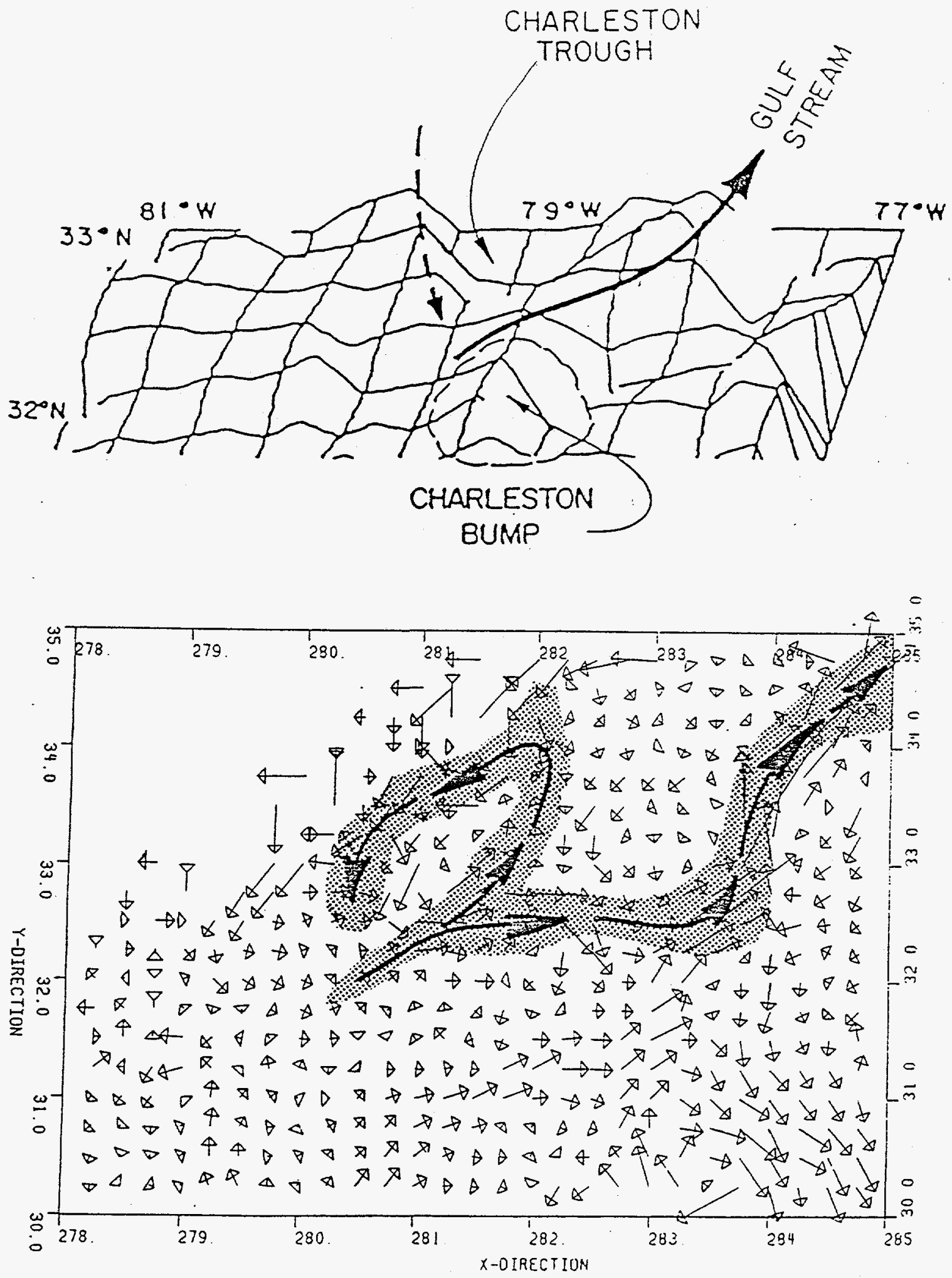

Figure 8. Seasurface topography (Derived from the Seasat altimeter) and geostrophic currents related to surface pressure gradients in the South Atlantic Bight. 
DW84ET

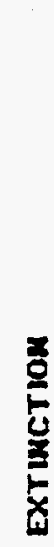

DW126ET

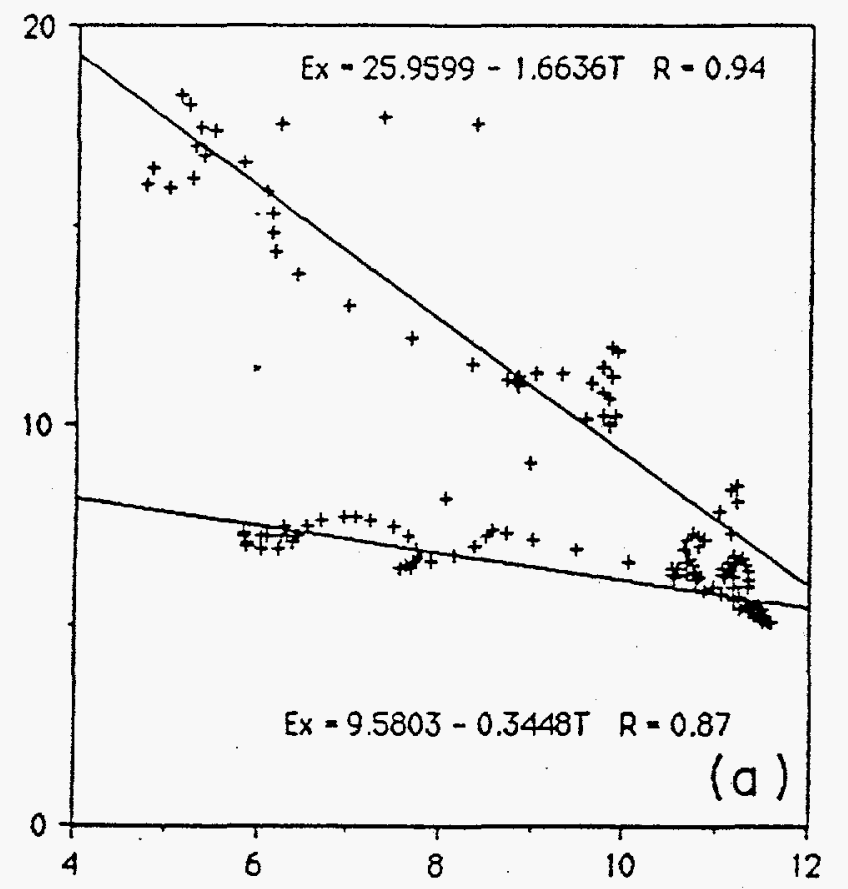

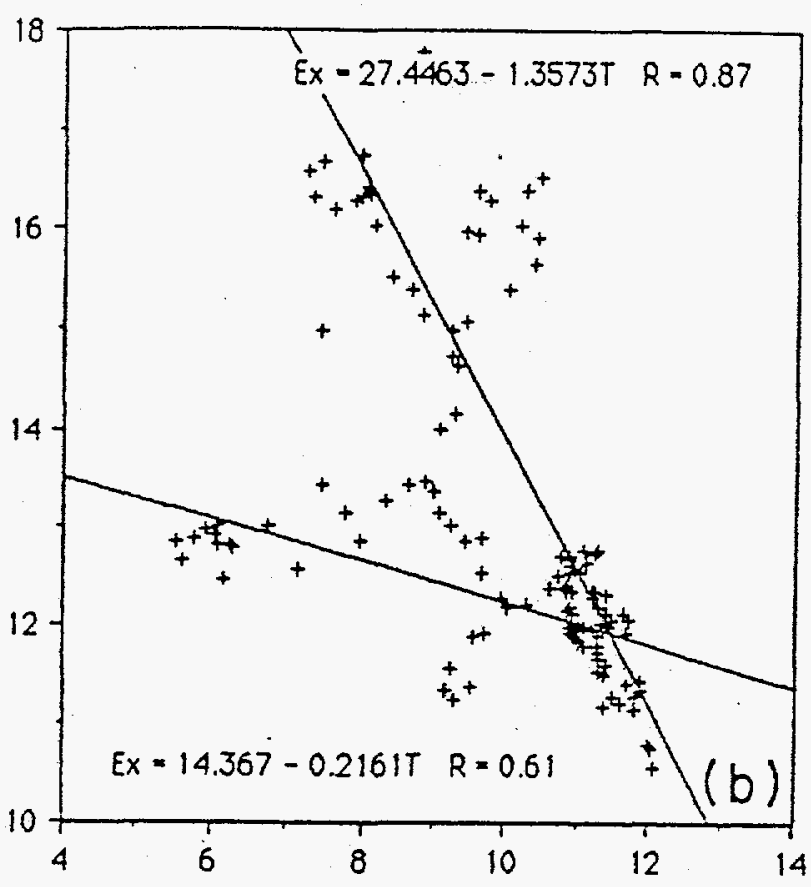

T

DW84EV

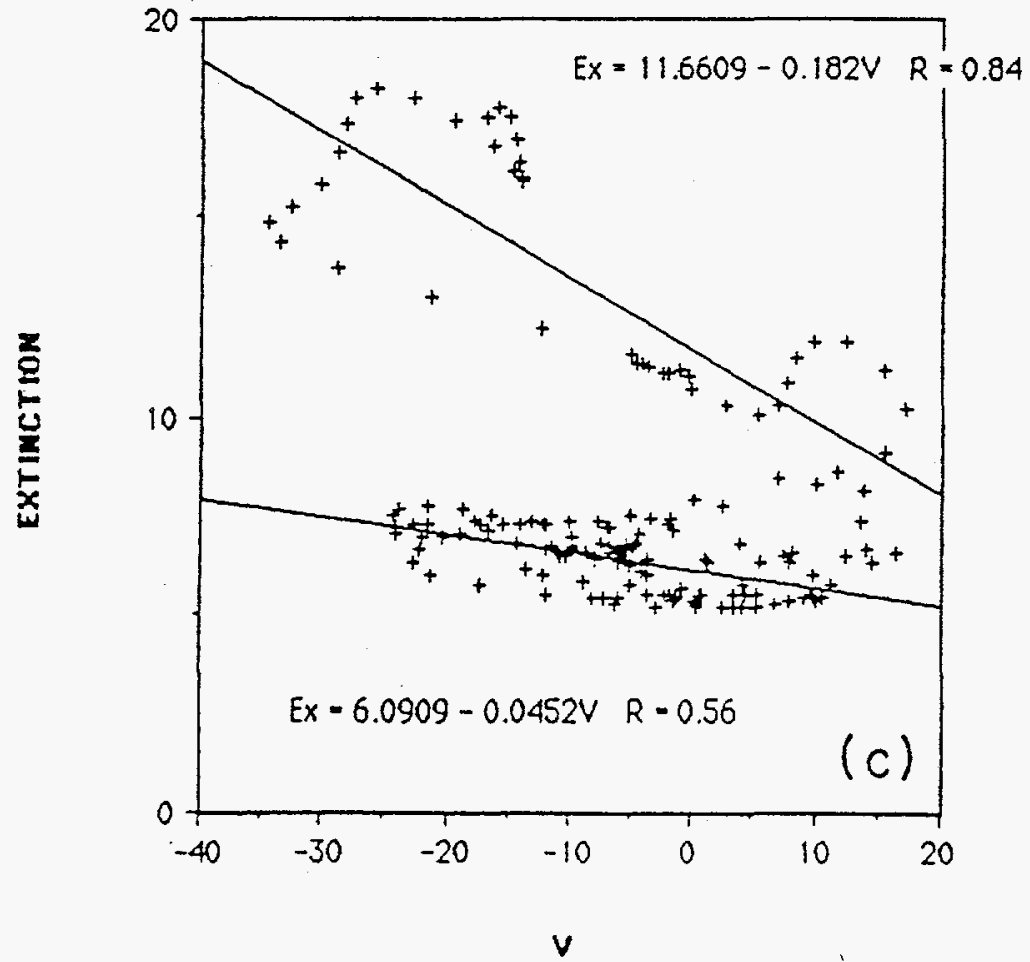

Figure 9. Transmissomer light extinction vs. (a) temperature at Site W8-4 (b) temperature at Site $W 12-6$ and (c) longshore current (positive to NE, negative to $S W$ ) at Site S $^{-4}$ during SEEP-I. (Note bifurcant relationships.) 
Bight (paper in press).

(n) Described upwelling mechanisms present in Western Boundary Current regions (paper in press).

(o) Mathematically modeled shelf currents during winter along a curved, cuspate coastline and introduced new boundary conditions (paper in review).

(p) Proved the M2 tide in both the MAB and SAB is baroclinic on the mid and outer shelf. Showed the presence of an internal wave field in both bights (paper in prep).

(q) Showed that particle presence is inversely related to temperature along two bifurcant (straight) lines which intersect at about $11.5^{\circ} \mathrm{C}$. For a specific temperature $\left(<11^{\circ} \mathrm{C}\right)$ two fairly distinct values of particle concentrations are evident. This phenomenon is not understood. Examples shown in Figures 9a,b. Also, particle presence is related in a bifurcant way to the parabathic velocity component (Figure 9c).

(r) Related \% variability due to wind and \% due to Gulf Stream on the outer shelf in the $\mathrm{SAB}$ (paper in review)

C. Awards Received because of DOE related research:

1. The George Deacon Award for Interdisciplinary Research on the Gulf Stream (to L.J. Pietrafesa).

2. Letter of Commendation * from (former) N.C. Governor James B. Hunt.

3. Letter of Commendation * from (present) N.C. Govern James A. Martin.

* for advice to the State concerning coastal environmental issues 
D. Thesis Awarded:

1. Gupton, F.M., June 1987. MS Thesis entitled: The Baroclinicty of the $\mathrm{M}_{2}$ tide in the Georgia Bight.

2. Askari, F., December, 1986. Ph.D. Thesis entitled: Winter Circulation in the Carolina Capes.

3. Zhang, Q.A., Dec., 1985. Ph.D. Thesis entitled: The Interaction . between Estuarine Plumes and Continent and Shelf Waters.

E. Theses and Dissertation in Progress:

1. Joyner, Elizabeth N. MS Thesis entitled Physical Coupling of Shelf and Estuarine Dependent Fish Larvae and Juveniles.

2. Lee, J.C., Ph.D. Dissertation entitled: On Kinematics and Dynamics of the Shelf/Slope Front During SEEP-I.

3. Liao, J. MS Thesis entitled Wind Forced Response of Long Waves and Currents in the Georgia Bight.

4. Kim, C. MS Thesis entitled: Internal Waves during SEEP-I, Spring, 84.

F. Papers published or Accepted for Publication:

Zhang, Q.H., G.S. Janowitz and L.J. Pietrafesa. The Interaction of Estuarine and Shelf Waters: A Model and Applications. J. of Physical Oceanography, Vol. 17, No. 5, 455-469.

Pietrafesa, L.J., G.S., Janowitz, T.Y. Chao, R.H. Weisberg, F. Askari and E. Noble. The Physical Oceanography of Pamlico Sound. NOAA Publication UNC-86-5, Nov. 86. 125 pps.

Pietrafesa, L.J. Gulf Stream and Wind Forced Capes. Oceanography of the Carolina Capes, ed. by R.Y. George.

Walsh, J.J., C.D. Wirick, L.J. Pietrafesa, T.E. Whitledge and F.E. Hoge. High Frequency Sampling of the 1984 Spring Bloom within the Mid Atlantic Bight. J. Continental Shelf Res.

Pietrafesa, L.J. and G.S. Janowitz. Physical Oceanographic Processes Affecting Larval Transport Around and Through North Carolina 
Inlets. Transactions of American Fisheries Society, Vol. 3, 34-50. Pietrafesa, L.J. Physical Dynamics of Boundary Current Upwelling. United Nations-UNESCO Publication.

Lee, T.N. and L.J. Pietrafesa. Summer Circulation on the Continental Shelf of the Southeast U.S. Progress in Oceanography.

G. Manuscripts - Submitted:

L.J. Pietrafesa, G.S. Janowitz and C. Sun. The instability of the Gulf Stream over variable topography. Re-submitted to J. Continental Shelf Research.

Pietrafesa, L.J. C. Sessions, G.S. Janowitz, C. Gabriel. The Invasion of the Red Tide into NC Coastal Waters. Submitted to Nature.

J. Santos, M. Wimbush, T.N. Lee, L.J. Pietrafesa. Gulf Stream and Wind Induced Current Variability on the Northeastern Florida Continental Shelf. J. Continental Shelf Research.

Askari, F., L.J. Pietrafesa and G.S. Janowitz. Model for winter circulation in Onslow Bay. J. Continental Shelf Research.

H. Manuscripts to be Submitted:

Pietrafesa, L.J. and M.P. McCann. Temperature and Salinity fluctuations on the North Carolina Cape Shoals: Communication Between the Mid and South Atlantic Bight. J. Continental Shelf Research.

Pietrafesa, L.J. and F. Askari. Internal Waves in the MAB and SAB. J. Continental Shelf Research.

Pietrafesa, L.J., J.J. Walsh, C.D. Warick, T.S. Hopkins and G.S. Janowitz. On the Calculation of Chlorophyl Flux During SEEP-I. J. Continental Shelf Research.

Lee, J.C., L.J. Pietrafesa, J.J. Walsh. Low Frequency Dynamics During SEEP-I. J. Continental Shelf Research. 
Pietrafesa, L.J. The manifestation of Gulf Stream frontal events in the North Carolina Capes. J. Continental Shelf Research.

Pietrafesa, L.J. and F. Askari. On the detection of Gulf Stream frontal filaments and the Charleston Trough by SEASAT satellite. J. Continental Shelf Research.

Janowitz, G.s. and L.J. Pietrafesa. The Evolution of the MAB/SSF. J.Geophys. Res.

Pietrafesa, L.J., G.S. Janowitz and M. Purba. The momentum balance on the inner to middle shelf of the South Atlantic Bight. J. Geophysical Research.

Pietrafesa, L.J. A Unified Theory of Fish Migration by Immature Fish on the North Carolina Coast. Limnol. and Oceanography.

I. Talks at National Meetings

1. Pietrafesa, L.J., Boundary Current Upwelling. UNESCO Conference, Florida State Univ., 1985 (Invited talk).

2. Pietrafesa, L.J. and C. Sun, Internal Waves during SEEP-I. EOS, Vol. 66, No. 16, 1985.

3. Pietrafesa, L.J., Kinematics and Dynamics during SEEP-I. EOS, Vol. 66, No. 16, 1985.

4. Pietrafesa, L.J., Abiotic Factors Affecting Larval Transport near Cape Hatteras. ERF., Univ. of New Hampshire, 1985. (Invited talk)

5. Janowitz and L.J. Pietrafesa, Interaction of Estuarine Plumes and Shelf Waters. ERF, Univ. of New Hampshire, 1985.

6. Pietrafesa, L.J., Transport Mechanisms in North Carolina Inlets. ACE, Univ. of Mississippi, 1985. (Invited talk) 
7. Pietrafesa, L.J., The Oceanography of the South Atlantic Bight. A Regional Report delivered at the NSF sponsored Co Po Workshop in Gulfport, Miss., January, 1988. Pietrafesa chosen to be Regional Subcommittee Chairman.

8. Pietrafesa, L.J., and J.M. Miller, Abiotic Factors Affecting Migrations of fish from the Gulfstream Front to Juvenile

- Nurseries in the Carolina Capes. EOS Vol. 67, No. 44, 0220-11 Nov. 1986.

9. Pietrafesa, L.J., Salinity Fluctuations in a Pamlico Sound Nursery. EOS Vol. 68, No. 16, May 87. (Invited Talk)

10. Janowitz, G.S., L.J. Pietrafesa, Q.H. Zhang, A model of the Interaction of Estuarine and Shelf Waters and Applications. EOS Vol. 68, No. 16, May 87.

11. Pietrafesa, L.J., Gulf Stream and Wind Events in the Carolina Capes. Marine Expo 1987, Oct, 1987. (Invited Talk)

12. Pietrafesa, L.J., NSF GOFS-CoPo Workshop in Gulfport, Miss., January, 1988. Regional overview of the physical oceanography of the South Atlantic Bight. (Chairman)

13. Pietrafesa, L.J., Manifestations of western boundary current upwelling. US - Taiwan Joint Workshop on Frontal Exchange Processes. May, 1988. Stony Brook, N.Y. - SUNY.

J. Other Exposure of DOE Results

1. Several newspaper articles discussing the MAB studies (SEEP-I and II) including results to date and ongoing efforts (see Appendix C).

2. Radio interview WRDU (FM-106.1) of 30 minutes about the DOE SEEP-II study on 08 May, 1988.

3. Radio interview about the Red Tide invasion into NC coastal waters via Gulf Stream filaments-aired on WPTF (AM-680) on 
05 April, 1988.

4. TV interview about the oceanographic conditions in the southern portion of the $\mathrm{MAB}$ as they relate to sealevel rise and migrating barrier islands - aired on WRAL (Chn. 5) on 08 July, 1988.

5. Served in the US delegation to the Taiwan-US/NSF sponsored workshop on Frontal Exchange Processes concerning a well designed field program to study the Kuroshio Current (the Black Stream). Helped design a 10-year long physical oceanographic field program of the Gulf Stream (sponsored by DOE). Delivered the lead talk.

6. Appeared before a National Academy of Sciences Panel assessing MMS-OCS studies. The DOE work constituted the positive side of continental margin oceanography (Nov., 1987, Georgetown). 